\title{
DECRIMINALIZATION OF GAMBLING IN UKRAINE: INTERNATIONAL EXPERIENCE
}

\author{
Oleg Grudzur ${ }^{1}$ \\ Viktoria Babanina ${ }^{2}$ \\ Vasyl Shakun ${ }^{3}$ \\ Viktor Sushchenko ${ }^{4}$ \\ Yuriy Harust $t^{5}$
}

\begin{abstract}
The relevance of this article is due to the fact that the entertainment sphere is one of the most important components of filling the national and world sectors of the country's economy. The purpose of the article is to carry out significance of the obtained results is reflected in the fact that this study may serve as a basis for outlining future changes to the current legislation of Ukraine on the gambling business functioning in Ukraine.
\end{abstract} scientific research on the functioning and overall reform of the gambling business in Ukraine, to study foreign experience of developed countries of the world in this field. The leading research methods are general scientific and specific research methods, including methods of logic, analysis, comparison etc. The results of this study are to identify the socio-economic grounds for legalizing gambling business in Ukraine and to outline a national legal mechanism for

Keywords: gambling games, corruption development, legalization of gambling, ban on gambling, shadow economy.

\section{Introduction \\ Gambling games, as a social phenomenon, arose at a certain stage of civilization, which contributed to the formation of a whole complex of inextricably linked relationships of a certain nature:}

\footnotetext{
${ }^{1}$ National Academy of Internal Affairs, Solomianska Square, 1, Kyiv, 03035, Ukraine. E-mail: oleg-gr22@uohk.com.cn

${ }^{2}$ National Academy of Internal Affairs, Solomianska Square, 1, Kyiv, 03035, Ukraine

${ }^{3}$ National Academy of Internal Affairs, Solomianska Square, 1, Kyiv, 03035, Ukraine

${ }^{4}$ National Academy of Internal Affairs, Solomianska Square, 1, Kyiv, 03035, Ukraine.

${ }^{5}$ Sumy State University, Rimsky-Korsakov Street, 2, Sumy, 40007, Ukraine
} 
emotional (thrill of the

competition, excitement in case of winning or losing);

- cognitive (interest in learning about a new phenomenon that is not imposed by the state, but is determined by personal will);

- economic (interest in winning, desire to have money to participate in the game);

- psychological (passion for the game, desire to participate in the game and win);

- $\quad$ legal (the need to regulate gambling relations);

- political (the

implementation by the state of promoting or prohibiting policy) (Kapitanenko, 2013).

The first mention of gambling appeared 3500 years BC, their history begins with the dice that were found during excavations in Greece and Egypt. The first gambling establishments existed during the time of Ancient Rome. In the Middle Ages gambling spread throughout Europe, becoming an integral part of the social activities of wealthy lords. Not every state has natural treasures that can ensure its prosperity for many years. It can be treated differently to the fact, that some countries earn on transit through their territory (Egypt, Panama), while others sell their labor force (Philippines, Pakistan, Bangladesh). But is it possible to criticize those countries that are trying to raise the standard of living of their citizens by legalized gambling. Nowadays, activities for the organization and conducting of gambling is officially authorized in all countries of Europe, except San Marino and Liechtenstein, in virtually all of North and South America (except Cuba), in many countries in Asia and Africa, Central America, Australia and Oceania. Moreover, the EU is preparing to adopt a single law for all members of the European community, after which discussions on the possible closure of the industry in non-EU countries will cease for many years (Kovtun, 2008; Harust et al., 2019; Manzhula et al., 2019).

Gambling has been developing very rapidly since independence in Ukraine. However, the Law of Ukraine "On Prohibition of Gambling in Ukraine" No. 1334-VI, adopted by the Verkhovna Rada of Ukraine on May 15, 2009, introduced a complete ban on gambling (Law of Ukraine "On Prohibition..., 2009), and the Law of Ukraine "On Amendments to Certain 
Legislative Acts of Ukraine on Improvement of the Law on Prohibition of Gambling in Ukraine" dated December 22, 2010 under No. 2852-VI (Law of Ukraine "On Amendments..., 2010) amended the Criminal Code of Ukraine by Article 203-2 “Occupation of the Gambling Industry". This Law of Ukraine, which came into force in 2011, introduced criminal liability for organizing and conducting business activities in the sphere related to gambling. The concept of "gambling" in our country is legally defined and is contained in Article 1 of the Law of Ukraine "On Prohibition of Gambling in Ukraine", which states that "gambling is an activity related to the organization, conduct and provision of access to gambling at casinos, gambling machines, computer simulators, in bookmakers, in online establishments, in electronic (virtual) casinos regardless of the location of the server" (Law of Ukraine "On Prohibition..., 2009).

The main reason for the ban on gambling is that according to Ukrainian society, gambling is a negative social phenomenon, which has an increased social risk. It is that a large amount of money is being accumulated in this field, from which gambling organizers do not pay taxes to the state, which deprives the budget of the country of significant cash flows, which are used to illegally enrichment and funding other illegal activities. S.V. Riabchuk draws attention to the fact that gambling is connected with committing other socially dangerous acts, such as bribery of officials of the controlling bodies, fraud, involvement of minors in criminal activity, legalization (laundering) of income obtained by criminal means, tax evasion, fees (compulsory payments) (Riabchuk, 2018). The conducted researches prove that the ban on gambling in 2009 did not produce the desired result and its complete termination, but on the contrary brought it out of the law and completely criminalized, creating a favorable environment for the development of corruption, development of the shadow market, led to withdrawal from the domestic economy billions of hryvnia (Rukhliadin and Stetsenko, 2011; Kucheriavyi, 2014; Ovcharenko, 2018).

\section{Materials and Methods}

The following methods were used during the research: general theoretical (analysis, synthesis, concretization, generalization, analogy 
method, modeling); empirical methods (research of experience of full or partial legalization of gambling business in Ukraine and abroad, research of normative-legal and scientificmethodical literature on the given issue, scientific researches and conclusions). Exploring the expediency of lifting the ban on gambling in Ukraine, it would be logical to analyze how these social relations are regulated in other countries of the world and to analyze different models of their functioning. Thus, modern scholars today distinguish three models of legal regulation of gambling entities:

1) partial legalization, envisaging the creation of special gaming zones outside settlements (EU countries, Finland, United Kingdom, Kazakhstan, Denmark, Austria);

2) a complete ban on the activities of such entities (Pakistan, Iran, Afghanistan, Saudi Arabia, Indonesia, Israel, Libya Bahrain);

3) full legalization of the gambling business, but only within the framework of strict state control and creation of special licensing conditions for this industry (USA, Ukraine until 2009) (Muliavka, 2010; Riabchuk, 2018).
For example, 48 states (out of 50) have been granted gambling permit by the authority in the US: there are gaming machines, bookmakers, racetracks, lotteries etc. Interestingly, the casino operates at this time only in two cities: Las Vegas (Nevada) and Atlantic City (New Jersey). According to the National Council on gambling addiction, about $1 \%$ of American adults can be considered pathological players, another $2-4 \%$ are close to it. Overall, $85 \%$ of residents played for money at least once in their lives. On July 21, 1998, the US Senate decided to ban gambling on the Internet with simultaneous permission, at the same time, use of the Internet for holding state lotteries and games in which they make a bet with each other (Riabchuk, 2018).

Considering that the European Union has no competence to regulate the field of gambling games and gambling business, accordingly, there is no EU common law on gambling, that is why the EU member states regulate this market independently. All EU countries have legislation on gambling. The overwhelming majority is characterized by the adoption of national legislation that establishes a uniform legal regime for gambling business throughout the 
country. There is no consensus among EU countries about the number of laws one or more - governing different types of gambling. Some countries have a single piece of legislation covering all gambling (for example Netherlands, Poland, Romania, Sweden). Other countries have followed the passage of industry laws (for example, in Ireland there are the law on gambling and lotteries and the law on bookmaking, in Italy each sector of gambling services is governed by separate legislation, in Lithuania there are laws on gambling and lottery) (Sergienko, 2015).

However, in individual (primarily federal) states, regional authorities have the power to enact local legislation governing gambling in their respective territories. For example, in Austria, the activities of casinos, lotteries, card games and poker are regulated at the federal level, and at the level of each member of the federation (land) - of sports bookmaking and slot machines outside the casino. In Spain the sphere of gambling is regulated both at central (national law) and at local level. Each of the autonomous communes passed its legislation on the basis of powers delegated by the central government. In Italy only casinos continue to be regulated locally. The particular situation is in Germany, where at the national level the Inter-Land Gambling Agreement is concluded and periodically updated, and each land adopts its own legislation in compliance with the conditions set out in this agreement. However, certain types of gambling and certain aspects of gambling are governed by federal laws.

In France gambling can only be done in cities with more than half a million people, and in the capital of the country it is generally forbidden. In the UK gambling establishments operate in 53 government-designated areas. There is only one casino in the whole country in Finland, and this type of business is allowed in China only in Macau. Australia is leading in the number of gambling machines, in which 200 thousand pieces account for 20 million people (Medytskyi, 2008). In the Swiss Constitution Article 106 is entirely devoted to the regulation of the gambling sector. It provides for such activities on the basis of a license issued, taking into account regional conditions and the risk of gambling. The Law "On Gambling and Gambling Houses", dated 1998, is effective in the development of the Constitution (Prykhodko, 2008). 
However, it should be noted that in order to improve European cooperation in this area, a Cooperation Agreement was concluded on 27 November 2015 between the regulatory authorities of the member states of the European economic area in the field of gambling for online gaming services. It should also be noted that in all EU countries gambling is legal, although in some of them it is substantially restricted in order to adequately protect and balance the interests of different groups of society. According to data posted on the European Commission's website, the gross profit of the European Union game market in 2015 was estimated at around $€ 91.6$ billion, of which $14 \%$ (about $€ 13$ billion) was from the online market, accordingly, 86\% (about $€ 78.6$ billion) is from the offline market. Bookmaking accounts for the largest share of the European Union's gambling market $33 \%$, poker and casinos account for $22 \%$ and $21 \%$ respectively, state lotteries account for only $11 \%$ of the market (Ovcharenko, 2018).

\section{Results and Discussion}

Summarizing the above, we can conclude that there is a certain pattern of annual growth in the volume of the gambling market in EU countries. But this is in the European Union, and it is probably irrelevant to compare it with Ukraine, given into account our mentality and level of social culture of citizens (Myrhorod-Karpova, 2019). That is why we have taken for conducting the research a country that has a historical path of development very close to us as well as the mentality close to the Ukrainians. In our view, the economic prosperity, that Georgia has achieved over the last decade, requires exploration of both the process of reforming the Georgian economy and borrowing from the Georgian experience, including in the field of gambling. Georgia's current legislation allows all types of gaming to be in the legal field. Among the main types are casinos, bookmaking business (including sweepstakes), lotteries, slot machines, gambling clubs. In the online segment the law allows for the organization of casinos, sweepstakes and slot machine salons. A peculiarity of gambling organization in Georgia is the fact that the existence of a real (terrestrial) gambling establishment is obligatory for the system of electronicgaming. Gambling in Georgia is 
governed by a number of legal acts, including:

- Georgian Law "On the Organization of Lotteries, Gambling and Profit Games” No. 1180 (Georgian Law “On the Organization..., 2005);

- Georgian Law "On

Licenses and Permits" No. 1775

(Georgian Law “On Licenses..., 2005);

- Georgian Law "On

Licensing and Permitting Fees" No. 2937 (Georgian Law “On Licensing..., 2003);

- Georgia Law "On

Gambling Charges” No. 4250 (Georgian Law “On Gaming..., 2006);

- Georgian Tax Code No. 3591 (Georgian Tax Code..., 2010);

- Joint Order of the

Minister of Finance and the Minister of Internal Affairs of Georgia "On Approval of the Rules of Checking the Exercise of the Permit of Gambling and Other Profitable Games by the Owners" No. 611-1013 (Joint Order of the Minister..., 2011).

In Georgia the procedures and requirements for obtaining a license to organize and conduct gambling are quite liberal. Companies registered in Georgia can be approved, but the owners of the companies can be both Georgian and foreign nationals. Georgia gambling permits are paid annually. Initially, the licensee pays for the first year of its activity, and then annually extends the validity of the permit by making the next payment. The amount of the permit fee depends on the venue of the gambling activity. The entities that organize this type of business in the resort areas pay the lowest fee for gaming licenses. Such a policy is aimed at developing Georgia's tourism infrastructure. For example, casinos and other gambling establishments in the resort cities of the country (Borjomi, Batumi, Kabuletti) enjoy considerable privileges when setting fees for the issuance of an operating permit. In particular, the annual fee for organization of casinos in Batumi is 250 thousand lari and in Tbilisi - 5 million lari. If this amount is transferred into national currency at the rate of the National Bank of Ukraine as of November 1, 2016, it will amount to about $€ 89,000$ in Batumi, and about $€$ 1.8 million in Tbilisi (Riabchuk, 2018).

It is worth noting that the licensee for the organization of casinos in Batumi places this institution in the territory of newly built hotels with at least 100 rooms, then he/she is exempted from paying for a permit for a 10 years' 
period. In addition, it is free of charge to organize casinos in the municipalities of Kazbegi, Tskaltubo and Signagi. The situation is similar with the amount of the fee for obtaining permits for other types of gambling (lotteries, bookmaking, gambling clubs). For example, the fee for a permit to organize a bookmaker's office in Tbilisi is 200 thousand lari per year, and in the administrative districts of Batumi, Kutaisi, Rustavi - only 80 thousand lari per year. Due to the legalization of Georgia's gambling business, it was possible to attract additional incomes to the country's budget. Gambling revenue is an important part of the local budgets of many cities and municipalities in Georgia. In 2014 this figure averaged $24 \%$ of the budgets of the six largest cities and the Kazbek municipality. Particularly noteworthy are the border settlements: Kazbegi (39\%), Batumi (34\%) and Zugdidi (32\%) (Serhiienko et al., 2015).

In view of the above mentioned, we have come to the conclusion that the experience of foreign countries in the field of gambling in filling the state budget, and that in almost all countries of the European Union and many developed countries of the world, gambling is in the legal field and works to develop the economy of the country is an example and the basis for the legalization of gambling in our country. The attitude to the issue of the legalization of gambling in Ukrainian society is different, but everyone is aware that with the proper level of control and regulation of gambling, it will still bring more public benefit than its prohibition. Thus, gambling, if properly regulated and controlled by the state, can benefit society by paying considerable taxes and filling the state budget. It should be noted that the cost of obtaining a license in accordance with the bills submitted to the Verkhovna Rada of Ukraine is approximately 50 million hryvnas, which is credited to the State Budget. We saw a positive experience of replenishing the state budget in our country in 2005, when the sphere of gambling was not forbidden, and the issuance of a lottery license cost $€ 30$ thousand, not taking into account the income from the profits and winnings of the institution, quite considerable amounts. The prior to the ban on gambling the profits from its operations amounted to 16 billion hryvnas annually. According to preliminary estimates, if the casinos are legalized with the 
appropriate cost of licensing, the state will receive over one billion hryvnias annually (Legitimate fraud...). It is normal practice to improve the economic situation through profit through legalization of the gambling business. As an example, France's elite casinos in resort cities pay to the state budget at least $80 \%$ of annual income, in Finland $70 \%$, the funds received go to the social needs of the population, namely to support the vulnerable segments of the population, the maintenance of orphans and prisoners (Table 1)

Table 1: Size of tax rates in European countries

\begin{tabular}{|c|c|c|}
\hline Country & Tax on gross gaming income & Turnover tax rates \\
\hline Austria & - & $2 \%$ \\
\hline Belgium & $\begin{array}{c}15 \% \text { (total rate) } \\
11 \% \text { (for online gambling) }\end{array}$ & - \\
\hline Bulgaria & $20 \%$ & - \\
\hline United Kingdom & $\begin{array}{c}15 \% \text { (total rate) } \\
50 \% \text { (land-based casino) }\end{array}$ & - \\
\hline Estonia & $5 \%$ & - \\
\hline Spain & $\begin{array}{l}10-25 \% \text { (depending on the } \\
\text { type of game) }\end{array}$ & - \\
\hline Italy & $20 \%$ & $\begin{array}{l}2-5 \% \text { (depending on the type of } \\
\text { game) }\end{array}$ \\
\hline Cyprus & $13 \%$ & - \\
\hline Latvia & $5 \%$ & - \\
\hline Malta & - & $0.5 \%$ \\
\hline Netherlands & $29 \%$ & - \\
\hline Germany & $\begin{array}{l}\text { 12-20\% (for gambling } \\
\text { machines) } \\
20-80 \% \text { (for a land-based } \\
\text { casino) }\end{array}$ & $5 \%$ (for bookmaking services) \\
\hline Poland & - & $\begin{array}{c}12 \% \text { (for bookmaking services) } \\
20 \% \text { (lottery) } \\
50 \% \text { (slot machines) }\end{array}$ \\
\hline Romania & $20 \%$ & - \\
\hline
\end{tabular}


165

France

$8.8 \%$

Source: made by the author on the basis of researches of I.V. Serhiienko, I.I. Fomina, and R.B. Khorolskoho (Serhiienko et al., 2015).

Discussions on the feasibility of legalizing gambling have been underway for more than a year, both in political and academic circles, and meanwhile the State Budget has been losing significant revenues that could have been used to improve the social situation in the country. Given the decline in socioeconomic development of Ukraine, the issue of legalization of gambling in Ukraine is extremely urgent. In order to formulate and implement an effective state policy in the field of gambling regulation in Ukraine, a draft Law of Ukraine "On State Regulation of Gambling Organization and Conduct" No. 2285 was registered (Law of Ukraine "On State..., 2019).

While conducting our research we can say that despite the ban on gambling in Ukraine and the introduction of criminal liability, it exists, is flourishing and in high demand among a large part of the population. Therefore, legalization and legal regulation of this area is necessary, but only under effective state control. In our opinion, it is better not to forbid what still exists, but to improve the very mechanism of existence of this business. Taking into account foreign experience, and according to the results of our research, we can say that Ukraine needs to develop its administrative and legal mechanism of decriminalization and legalization of the gambling business, taking into account the mentality of Ukrainians. Gambling places must be clearly identified. We suggest to place gambling rooms at five star hotels and international airports. In turn, the area of the playroom should not be less than 1000 square meters. This, in turn, will ensure the inaccessibility of gambling establishments of socially disadvantaged sections of the population, minors and the poor. At the same time to allow to equip no more than one casino for 300 thousand persons in one regional center, and in the region - up to one casino for 500 thousand persons.

It is also necessary to set clear requirements for the financial capacity of the organizers of the gambling establishment. This will ensure the financial stability of the institution and 
guarantee the ability to pay the winnings. Therefore, the founders should be legal entities that have their registered capital of at least $€ 4$ million. This capital must be formed without the involvement of sponsorships, patrons and credit. The guarantor of the fair conduct of the gambling business by the organizers of the institutions should be subject to rigid financial sanctions, penalties and punishments, which will be imposed on the offender in connection with the violation of the requirements for conducting this type of business.

In our opinion, one of the main factors in the legal support of the gambling business is the creation of an effective state control system, and the relevant state institutions should be entrusted with a number of functions and powers, such as the granting of licenses, the function of controlling the activity and observing the rules and regulations of doing business. In our view, it would be advisable to set up two regulatory bodies, that will exercise control. The first is a state body, and the second is on the side of the independent public. However, state control over the provision of gambling services should be carried out centrally, within one body. This body should be a structural unit with a special status in the gambling sector regulation under the Ministry of Finance of Ukraine. To do this, it is necessary to create a Gambling Market Regulation Department and concentrate all regulatory functions at the national level within a single body. This, in turn, will simplify and make transparent the very process of granting licenses and permits to gambling entities, and it will enable effective control, within the limits of one state body, over the gambling companies' activities. As this body will be partially controlled by independent public bodies, the corruptive component of the body's activity will be eliminated.

Along with the creation of a new body, we believe that it is appropriate to create a new licensing system in the gambling market, namely by increasing their value. This, in turn, will provide a fiscal function, namely, it will provide a certain barrier to entry of "dishonest" companies into the market of gambling services and will provide a way of receiving funds into the budget of Ukraine. Licensing will allow to keep a register of companies in the gambling market and, based on this number, change the parameters of certain licenses. 
Also, there should be a complete ban on gambling in unauthorized places, namely - in underground passages, entertaining complexes, restaurants in any other establishments not provided by law, in case of violation, the organizers should be held financially responsible. Compliance with this regulatory framework and its implementation must be shared between a specially authorized body, namely the Gambling Market Regulation Department and local authorities. For example, local executive bodies should designate places for gambling establishments that do not violate the rules of the gambling market law, and the Department should monitor compliance with these rules.

We also consider it advisable to introduce a mandatory ticket for casino visitors. The cost of one ticket must be at least 100 tax-free minimum incomes of citizens, which will make it impossible to access gambling establishments of the "poor" sections of the population. The system of taxation of gambling business seems to us of a mixed type, namely: tax on the operating result of the activity of a gambling establishment and tax depending on the amount of gambling equipment (patent). Fines also should be increased for persons who will open gambling establishments without licenses or violated business requirements. The fine should be 2 thousand minimum wages, as well as confiscation of all profits to the State Budget of Ukraine. In addition to paying for the license fee, gambling owners will be required to pay contributions to the state budget, which will be a monthly additional payment for each slot machine.

In order to exclude any corruption component in the conduct of the gambling business, we propose to introduce an electronic register, which will include gambling establishments, which will be imposed software for the control of rates, payment of winnings, from which state taxes will be paid. Simply said, we propose to introduce the following gambling system: obtaining a license - entering the gambling in the appropriate registry, installing software for gambling control, which transmits data on information on accepted rates, paid winnings through the Internet to the Authorized Supervisory Authority - as a result of taxes paid to the State Budget. Such a system is sufficiently clear and transparent to allow the monitoring of the institution's activities through an 
electronic system that eliminates the influence of the human factor and prevents corruption.

In the course of our research, we have come to the conclusion that in the case of decriminalization, legalization and effective legal regulation, the sphere of gambling will bring considerable income to the country and significantly reduce the shadow economy. The proposed gambling development strategies will move gambling to a new European level of development. The adoption of the proposed procedures will also minimize public harm, risks to society and vulnerable sections of the population from conducting gambling business, create additional jobs and increase additional revenues to the State Budget of Ukraine.

\section{Conclusion}

Investigating the issues of legalization and decriminalization of the gambling business in Ukraine, we can say that in addition to financial prospects and the emergence of an additional source of revenue to the State Budget, it is possible to increase the tourist attractiveness of our country. Confirmation of this is the experience of
Singapore in 2010, when gambling was legalized in the country. Then in just one year the state budget was replenished by $\$ 5$ billion, and tourist visits to the country increased to 11 million people a year. Also, the creation of about 8,000 jobs could be a social basis for legalization, enabling the work of the population of the regions and significant contributions to social and pension funds. In addition to payments to the budget, the legalization of bookmaking activities will have a positive impact on several areas of life. First and foremost, it is the development and promotion of sports. Gaming companies around the world are sponsoring contracts with well-known sports brands and not-sopopular local teams, organizing and sponsoring tournaments of various levels. This allows the development of sports, creating the necessary conditions for this, as well as support state activities in this direction.

Legalizing and decriminalizing gambling also will serve as an impetus for infrastructure development, because the places where people will be allowed to gamble at the legislative level we suggest placing in remote cities, where it will be quite perspective to place these establishments, and their placement will 
bring benefits for the construction of infrastructure, road pavements, tourism business development. As a conclusion, it is advisable to emphasize that decriminalizing the gambling business will contribute to the economic development of our country and will benefit the Ukrainian society by filling the state budget, developing infrastructure, tourism and creating new jobs. The most important lifting of the ban will have a positive effect on reducing the level of corruption in Ukraine. After all, one of the criminal financial sources of corruption is the gambling business, which brings more than $\$ 5$ billion in shadows to corruption each year. Only in Kyiv the profits from the game are about one billion.

Thus, the profit from gambling is super-profitable, therefore, the criminalization of this area and corruption in the bodies that should ensure the detection of institutions that conduct illegal activity is sufficiently developed at all levels of government bodies. The very policy of banning gambling has provoked corrupt practices. Instead of the option of legalizing the gambling business and filling the state budget with taxes, it is easier for deputies to fill their pockets with criminal shadow bribes.

In examining the statistics on the conduct of checks on illegal gaming establishments, we have noticed that these are isolated checks of a demonstrative nature, as most establishments start their full work again after some time. An example of this is the continued resonance in the media, domestic law enforcement agencies on open criminal proceedings concerning the activities of illegal gambling establishments and a large number of searches conducted with the seizure of equipment, money and computer equipment. For example, in the last year only, according to the Ministry of Internal Affairs, 744 business entities illegally providing gambling services were identified and terminated in Kyiv. In the course of the criminal proceedings opened under Article 203-2 of the Criminal Code of Ukraine, more than 3600 gaming machines, almost 400 computers with integrated gaming machine simulations, 72 poker tables, 8 roulette tables and over 13200 chips were seized. However, as journalists later prove in their journalistic investigations, gambling organizers close criminal proceedings through the 
court, return the foreclosed property, and subsequently resume their activities after a some time. It is difficult not to mention that in this case there was corruption.

Analyzing the above mentioned statistics, the Kyiv city police on average found two or more such illegal gaming establishments daily, while working without days off and public holidays. And the sheer number of subjects of illegal criminal business proves that the 2009 Law in Ukraine is not actually being implemented. But to find out is only the beginning of the case, it is necessary to document the existence of a crime, establish the circle of persons involved in it, take measures to detain them, conduct a pre-trial investigation and prove the guilt of the organizers of illegal business. It really is a bunch of work, if it is done as it should in all the rules of criminal procedure law. It seems that gambling is an invincible hydra, in which two heads grow instead of one severed head. Is that why some people are tempted to act on the rule: if you cannot eliminate the problem, you must lead it by taking bribes for illegal acts.

Illegal gambling halls exist outside the law today and are in demand, and if so, it is a corruption factor that, at the expense of the material component, allows the bodies called to combat it to ignore certain entities engaged in such business. Therefore, we believe that the legalization and decriminalization of the gambling business minimizes corruption in the state bodies, regarding the "protection racket" of the activity of illegal gambling halls, and that criminal shadow money from the gambling business goes not into the thieves' pocket but into the state budget in the form of payment for permits and taxes.

\section{References:}

Georgian Law "On Gaming Charges" No. $4250 . \quad$ (2006). https://matsne.gov.ge/ru/document/view 122828 .

Georgian Law "On Licenses and Permits" No. $1775 . \quad$ (2005). https://matsne.gov.ge/ru/document/view 126824.

Georgian Law "On Licensing and Permitting Fees" No. 2937 (2003). http://extwprlegs1.fao.org/docs/pdf/geo 181475ENG.pdf.

Georgian Law "On the Organization of Lotteries, Gambling and Profit Games" No. $1180 . \quad$ (2005). https://matsne.gov.ge/ru/document/view /30988? publication=31. 
Georgian Tax Code No. 3591. (2010). https://www.refworld.org.ru/pdfid/548f 00b54.pdf.

Harust Yu, Melnyk V, Kiiashko Yu, Halunko V. (2019). Economic crime, innovative mechanisms of counteraction by law enforcement agencies. Asia Life Sciences, 2, 145-162.

Joint Order of the Minister of Finance and the Minister of Internal Affairs of Georgia "On Approval of the Rules for Checking the Exercise of the Permit of Gambling and Other Profitable Games by the Owners" No. 611-1013. (2011). https://feao.org.ua/wpcontent/uploads/2016/09/FEAO_Gambl ing_A5_04_print.pdf.

Kapitanenko NP. (2013). Gambling as a social phenomenon: historical and legal aspects. Law of Ukraine, 3, 33-37.

Kovtun YV. (2008). Legal Regulation of Gambling Business in Ukraine and Foreign Countries. Kyiv: IHROK, 135.

Kucheriavyi II. (2014). Actual problems of counteraction to gambling in Ukraine. Scientific Bulletin of Uzhgorod National University, 26, 208-210.

Law of Ukraine "On Amendments to Certain Legislative Acts of Ukraine on Improvement of the Law on Prohibition of Gambling in Ukraine". (2010). https://zakon.rada.gov.ua/laws/show/28 52-17.
Law of Ukraine "On Prohibition of Gambling in Ukraine”. (2009). https://zakon.rada.gov.ua/laws/show/13 34-17.

Law of Ukraine "On State Regulation of Gambling Organization and Conduct" No. $2285 . \quad$ (2019). https://w1.c1.rada.gov.ua/pls/zweb2/we bproc4_1?pf3511=67118.

Legitimate fraud or whoever rips the jackpot in Ukraine. http://www.abukr.net/uzakonenijobman-abo-hto-zrivaie-dzhek-pot-vukrayinii.html.

Manzhula A, Harust Y, MyrhorodKarpova V, Sobol Y. (2019). Search for ways to optimize the activities of state bodies managing the funds of international technical assistance. Asia Life Sciences, 2, 119-129.

Medytskyi IB. (2008). Gameplay as a background crime (problem statement). State and Law: a Collection of Scientific Works, 3, 498-504.

Muliavka DH. (2010). Polish experience in taxing gambling. Scientific Bulletin of The National University of Ukraine, 49, 142-153.

Ovcharenko AI. (2018). Legalization of gambling on the territory of Ukraine. Young Scientist, 4(56), 734-739.

Prykhodko DS. (2008). Legislative issues and some solutions to counteract crime in the field of gaming. Scientific 
Bulletin of Dnipropetrovsk State University of Internal Affairs, 4(40), 350-358.

Riabchuk SV. (2018). Criminological characteristics and prevention of gambling. Kharkiv: National Academy of Legal Sciences of Ukraine, 225.

Rukhliadin V, Stetsenko I. (2011). State and prospects of gambling business development. Economy, 3(110), 47-49.

Serhiienko IV, Fomina IY, Khorolskyi RB. (2015). Legal regulation of gambling: European experience, practice in post-Soviet countries, prospects of Ukraine. Kyiv: "Fomin, Sergienko \& Partners" Law Firm, 136 